\title{
Peripheral and central giant cell lesions: etiology, origin of giant cells, diagnosis and treatment
}

\author{
Lesão periférica e lesão central de células gigantes: etiologia, origem \\ das células gigantes, diagnóstico e tratamento
}

Rodrigo Gadelha Vasconcelos ${ }^{1}$; Marcelo Gadelha Vasconcelos²; Lélia Maria Guedes Queiroz ${ }^{3}$

\begin{abstract}
Introduction and objective: The peripheral and central giant cell lesions (PGCL and CGCL) are a group of pathological entities with similar histopathological features and whose origin has not been fully elucidated. The former is reactive and the latter exhibits a nonneoplastic proliferative behavior. This article aims to review the literature on peripheral giant cell lesions (PGCL) and central giant cell lesions (CGCL) by discussing the most important aspects pertaining to each of them. Results: These lesions are found in different locations and show diverse clinical signs despite having the same histopathological features. The treatment consists in the surgical resection by different techniques depending on the type of the lesion and clinical conditions. In the case of CGCL, drug therapy may also be employed. Conclusion: Although there is no consensus in the literature, it is essential to know the etiology of these lesions as well as the exact origin of the giant cells. Due to their singular biological behavior, it is of utmost importance to establish a differential diagnosis between the two lesions and other processes that have similar clinical, radiological and histological characteristics, inasmuch as this procedure is essential to provide a suitable treatment and establish a prognosis.
\end{abstract}

Key words: peripheral giant cell lesions; central giant cell lesions; gingiva; maxilla; mandible.

\section{INTRODUCTION}

Peripheral giant cell lesions (PGCL) are reactive, extraosseous (soft gum tissue) and exophytic, located in the alveolar ridge in edentulous area or in the gum. It usually occurs as a result of local irritants such as bacterial plaque, calculus, food retention, chronic infections, chronic irritation, trauma related to exodontia, poorly finished fillings, poorly fitted dental prostheses, occlusal forces and supernumerary teeth. The lesion arises from the periodontal ligament or mucoperiosteum and has low recurrence, mainly if the local irritant factor is eliminated $(2,3,5,8,11,20)$.
Central giant cell lesions (CGCL) are intraosseous nonproliferative lesions whose etiology is unknown. It is less common than PGCL and occur exclusively in maxillary bones ${ }^{(6,17)}$. It has variable clinical manifestations and may present slow asymptomatic growth with no recurrence or rapid painful growth with recurrence ${ }^{(6,8,9,22,28,30)}$.

As to histology, both lesions are similar. However, their behavior differs in terms of aggressiveness. CGCL are generally more invasive and tend to recur, whereas PGCL may have at most superficial bone resorption ${ }^{(1,14-17,19,36)}$. As PGCL bear close microscopic resemblance to CGCL, some pathologists acknowledge that it may represent a counterpart of the soft tissue of the central bone lesion ${ }^{(11,20,34)}$.

First submission on $08 / 05 / 13$; last submission on 24/09/13; accepted for publication on 25/09/13; published on 20/12/13

1. MSc in Dentistry by Universidade Federal do Rio Grande do Norte (UFRN); professor at Universidade Estadual da Paraíba (UEPB); doctoral student at the Post-graduation program in Pathology - UFRN.

2. Doctor in Oral Pathology by UFRN; navy officer

3. Doctor in Oral Pathology by Universidade de São Paulo (USP); professor at the Post-graduation program in Oral Pathology - UFRN. 
Some studies have tried to investigate the differences between the behavior of PGCL and CGCL as well as the probable origin of giant cells present in these lesions. Thus, this study aims to perform a review of the literature on PGCL and CGCL by discussing the most important aspects pertaining to each of them.

\section{REVIEW OF LITERATURE}

\section{Peripheral giant cell lesions}

The peripheral giant cell granuloma, also known as giant cell epulis, PGCL or giant cell hyperplasia, is the most common giant cell lesion in the oral cavity. It does not constitute a true neoplasm, but rather a reactive lesion caused by local irritation or trauma. Moreover, its etiology is still contentious. Previously, the lesion was called peripheral giant cell reparative granuloma. However, its reparative effect has not been proved yet, hence osteoclast activity seems doubtful ${ }^{(11,20,34) \text {. }}$

Clinically, PGCL appear as a soft extraosseous reddish purple or purplish blue lump with smooth shiny or papillomatous surface. It is a well-defined lesion with exophytic growth. Additionally, it may be pedunculated, sessile or it may not present areas of ulceration ${ }^{2}$ $11,12,20,27,31,34)$. It may develop at any age, predominantly in the first to sixth decade of life, especially from 31 to 41 years of age. Approximately $60 \%$ of cases occur in women. As to location, the lesion may arise in both the anterior and posterior regions of the gingiva or alveolar ridge. The mandible is more affected than the maxilla ${ }^{(20,21)}$. PGCL may also arise in areas adjacent to dental implants ${ }^{(31)}$.

Although PGCL arise in soft tissues, the "cup-shaped" resorption of the subjacent alveolar bone may be occasionally observed $^{(27,31)}$. Thus, it may be difficult to determine whether the increased volume originates from a PGCL or a CGCL that ruptured the cortical bone and invaded the gingival soft tissues ${ }^{2}$ 3, 21). According to Fanourakis et al. ${ }^{(12)}$, radiological examination is essential to determine if the lesion arises from the gingiva (peripheral) or bone (central) growing towards the surface. Dental resorption is rare ${ }^{(3,20)}$.

In terms of histology, there is an unencapsulated tissue mass with acute and/or chronic inflammatory infiltrate permeating highly cellularized fibrous tissue with foci of hemorrhage and deposition of hemosiderin. There is vascular proliferation and multinucleated giant cells permeated by massive oval to spindleshaped mesenchymal cells (Figure 1). Giant cells have various shapes and sizes, typically containing 8 to 15 nuclei. They may also be observed in areas of mature or immature reactive bone formation or dystrophic calcifications. The epithelial lining may be hyperplastic and/or ulcerated ${ }^{(11,20,34)}$. Two types of giant cells have been described: type A cells, which correspond to eosinophilic polynuclear cells with abundant and diffuse cytoplasm and irregular nuclei, containing chromatin spread along the inner membrane; type B cells, which have regular and well-defined shape and more abundant and dense cytoplasm ${ }^{(12,16)}$.

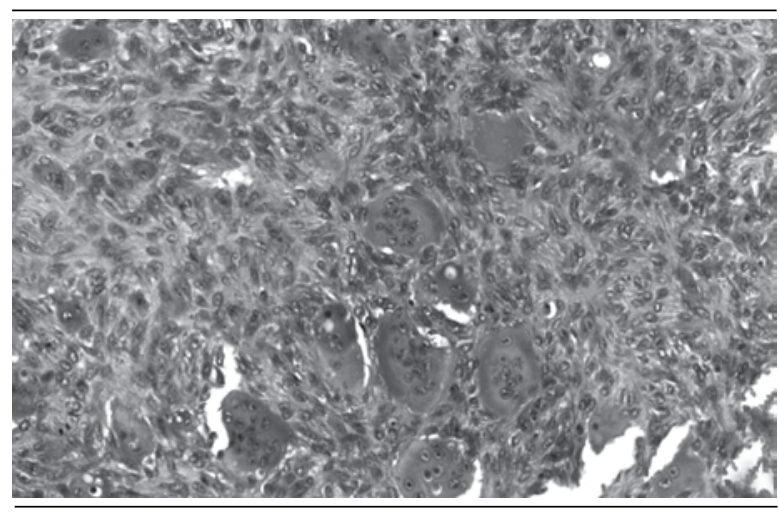

FIGURE 1 - Photomicrography showing a PGCL (HE)

PGCL: peripheral giant cell lesion; HE: hematoxylin and eosin.

The differential diagnosis of peripheral giant cell granuloma includes lesions with very similar clinical and histopathological features such as CGCL, pyogenic granuloma, peripheral ossifying fibroma, fibrous hyperplasia, inflamed irritation fibroma, hemangioma, lymphangioma, amelanotic melanoma and metastatic tumors ${ }^{(3,20,21,34)}$.

As the exact origin of the giant cells remains unclear, several hypotheses have been proposed to explain their proliferation: osteoblasts, phagocytes reacting to hemorrhage, endothelial cells, spindle-shaped mesenchymal cells, foreign body cells and osteoclasts ${ }^{(12,16,20)}$. It is assumed that giant cells may be osteoclasts remaining from the physiological resorption of deciduous teeth. Other authors claim that giant cells may simply constitute a reactive component of the lesion and they may be derived from mononuclear cells originating from the bone marrow. As it has been demonstrated by immunohistochemistry, giant cells have membrane receptors for calcitonin, which characterizes osteoclast activity. Another possibility is that they are formed by mononuclear cells from the phagocytic system ${ }^{(11,20,34)}$.

Stromal mononuclear cells (monocytes and macrophages) may participate in the formation of multinucleated giant cells through two members of the tumor necrosis factor (TNF) group: receptor activator of nuclear factor- $\kappa \beta$ ligand (RANKL) and osteoprotegerin $(\mathrm{OPG})$. The transmembrane molecule RANKL is produced by osteoblasts/stromal cells and binds to its RANK receptor, which is located on the surface of osteoclast progenitor cells (undifferentiated 
osteoclasts). RANK - RANKL binding promotes the differentiation of osteoclast progenitor cells into mature osteoclasts. $\mathrm{OPG}$, also produced by osteoblasts/ stromal cells, competitively binds to RANKL, neutralizing and blocking its binding to the RANK receptor, thus resulting in the reduction of osteoclastogenesis ${ }^{(12,16)}$.

It has been demonstrated that only mononuclear cells from both lesions (PGCL and CGCL) are positive for Ki -67 and, therefore, have proliferative activity. This finding would explain the fact that the aggressiveness of the lesion is promoted by the proliferative activity of mononuclear cells and not giant cells ${ }^{(33)}$.

As to treatment, the local surgical resection of the lesion is regarded as the most suitable approach. However, relapses may occur due to inadequate surgical technique, mainly when the surgeon does not effectively curette the periosteum subjacent to the lesion or small portions of the lesion remain within the tissues and proliferate afterwards, which promotes recurrence ${ }^{(2,21,34)}$.

\section{Central giant cell lesions}

The central giant cell granuloma, also known as CGCL or giant cell lesion, was first described by Jaffe in 1953. Although there is not enough evidence that this lesion promotes reparative process, it was denominated reparative giant cell granuloma ${ }^{(2,25-30)}$. Based on differences in their histological pattern and clinical behavior, Jaffe separated maxillary CGCL from long bone giant cell tumor. He suggested that CGCL are not a neoplasia, but rather reactive in nature, hence the term reparative giant cell granuloma. Due to the aggressive behavior often observed in CGCL, the term "reparative" was dropped. Furthermore, the distinction between maxillary and extragnathic lesions has been questioned. In a clinical and histomorphological comparison between giant cell tumor and CGCL, only the number of nuclei present in the giant cells was significantly different. Some authors concluded that the giant cell tumor and CGCL represent different spectra of a single pathological process ${ }^{(25)}$. Conversely, some authors claim that CGCL actually constitute a benign tumor ${ }^{(37)}$.

Regarding etiology, which is a much debated topic, there are local and systemic factors as well as possible mutations described in exons 3,4,9 and 11 of SH3BP2 gene ${ }^{(5,35)}$. Nevertheless, the study by Teixeira et al. ${ }^{(35)}$ only found associations with exon 4 and the remaining ones would be more related to cherubism. Local factors comprise traumas and vascular damage, which produce intramedullary hemorrhage and intraosseous replacement fibrosis. Among the systemic causes, it is particularly worth mentioning neurofibromatosis type I, Noonam syndrome, Ramon syndrome, Jaffe - Campanacci syndrome, association with cherubism, pregnancy and hormonal disorders such as hyperparathyroidism. No consensus has been reached as to a single etiology of $\mathrm{CGCL}^{(25-27,29,37)}$.
There is also evidence that the gene SH3BP2 is responsible for an increase in the activity of osteoblasts and osteoclasts, which are observed when normal teeth are coming through. Other reports have suggested that point mutations in the gene SH3BP2 could cause pathological activation of osteoclasts, presumably by dysfunction of the gene SH3BP2 on the regulatory pathway of osteoclastogenesis. In this process, the gene SH3BP2 influences the regulation of the parathyroid hormone (PTH) and $\mathrm{PTH}$ -related protein (PTHrP) receptors. This mediates a reduction in the expression of osteoprotegerin in dental follicle cells, which promotes osteoclastogenesis. There is also the possibility that the mutation in the gene SH3BP2 may exert some influence on the MSX-1 gene involved in regulating dental development. Accordingly, the development of CGCL may be associated with an imbalance of MSX-1, which could lead to a failure in osteoclast differentiation ${ }^{(25,30)}$.

CGCL display variable clinical behavior, including slow asymptomatic growth without recurrence and fast painful growth with perforation of the cortical bone plate and ulceration of the mucosal surface. This lesion affects patients aged 2 to 80 years, although most cases are below 30 years of age. The female gender is the most affected, possibly due to hormonal factors (pregnancy and estrogen) despite the fact that the lesions rarely express estrogen receptors ${ }^{26,30,37)}$. CGCL are more common in the anterior portion of the mandible and often cross the midline ${ }^{(6-8,22,25,27,30)}$. When CGCL affect multiple locations simultaneously, they are generally associated with hereditary syndromes or systemic diseases such as brown tumor of hyperparathyroidism, fibrous dysplasia, ossifying fibroma, Paget's disease or fibro-osseous lesion ${ }^{(26)}$.

Radiographically, the image evidences uni or multilocular well-defined radiolucent bone defects of variable size, depending on the aggressiveness of the lesion (Figure 2). Moreover, displacement of teeth, root resorption and perforation of the cortical bone may be observed ${ }^{(2,6,22,24,25,36,37)}$.

Based on clinical and radiographic features, CGCL fall in two categories: non-aggressive and aggressive. The former lesions account for most cases. Furthermore, they show little or no symptoms whatsoever and slow growth without perforation of the cortical bone and root resorption of the teeth involved. The latter lesions cause pain and exhibit rapid growth, usually larger than five centimeters, producing expansion and perforation of the cortical bone, displacement of teeth and root resorption. Besides, there is a high recurrence rate, which generally ranges between $37.5 \%$ and $70 \%(7,8,14,15,25,26,29,30,32,37)$.

Histologically, the lesion is characterized by dense proliferation of oval or spindle-shaped mesenchymal cells as well as a varying 

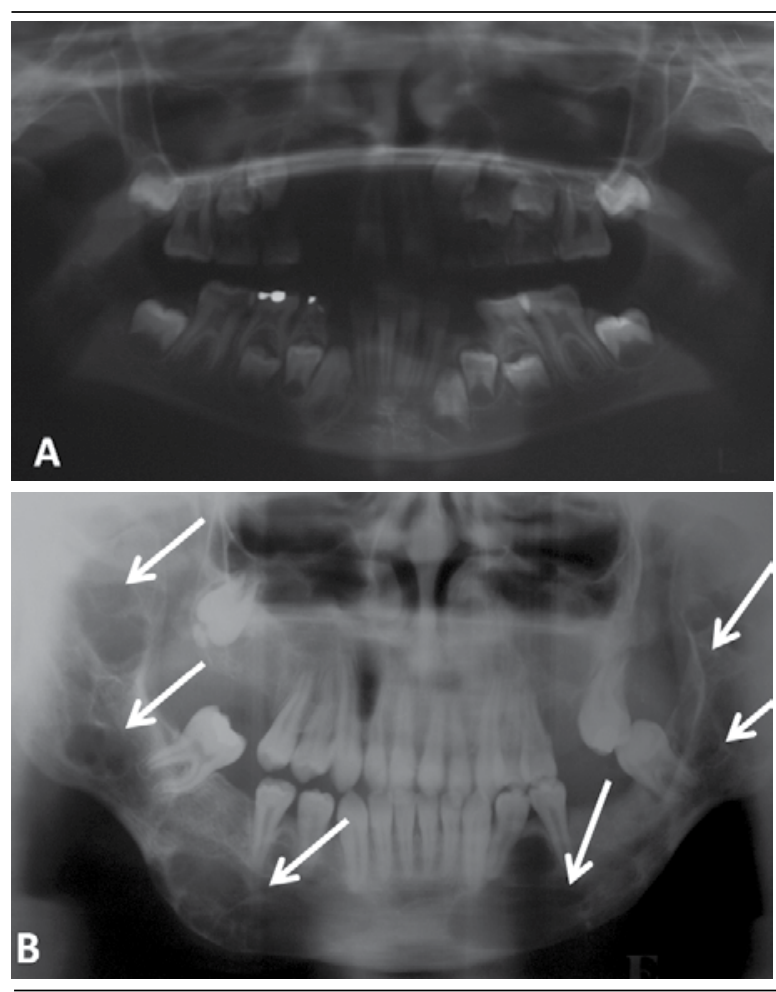

FIGURE 2 - Panoramic image showing two CGCL

A: unilocular radiolucent bone defect; B: multilocular well-defined radiolucent bone defects of varying sizes.

number of multinucleated giant cells containing 4 to 20 nuclei (aggregated or not) dispersed in the fibrous stroma in a perivascular or adjacent position to areas of hemorrhage (Figures 3 and 4) Round macrophages, deposition of hemosiderin, extravasated erythrocytes, foci of osteoid material (bone trabeculae), dystrophic calcification and predominantly mononuclear inflammatory infiltrate, particularly surrounding the periphery of the lesion, are also found ${ }^{(2,6,8,14,19,22,25,28,36,37)}$. Although multinucleated giant cells are present in large quantity, they are not regarded as proliferative cells. Macrophages, mesenchymal cells and fibroblasts have been considered accountable for the lesion growth ${ }^{(13,14,25)}$. These cells release cytokines that stimulate the proliferation and recruitment of blood monocytes to become osteoclast-like. Thus, the multinucleated giant cells are responsible for bone resorption and, consequently, the local progression of the lesion ${ }^{(13)}$.

Giant cells may be small and irregular with few nuclei or large and round containing twenty or more nuclei. It is debatable whether the lesions that have a greater number of giant cells with multiple nuclei and densely cellular stroma are more aggressive and more likely to relapse after surgical treatment ${ }^{(13,14,21,27)}$. By means of histomorphometric analysis, Reddy et al. ${ }^{(30)}$ revealed significant differences in the number of giant cells in aggressive and non- aggressive lesions, although there was no statistically

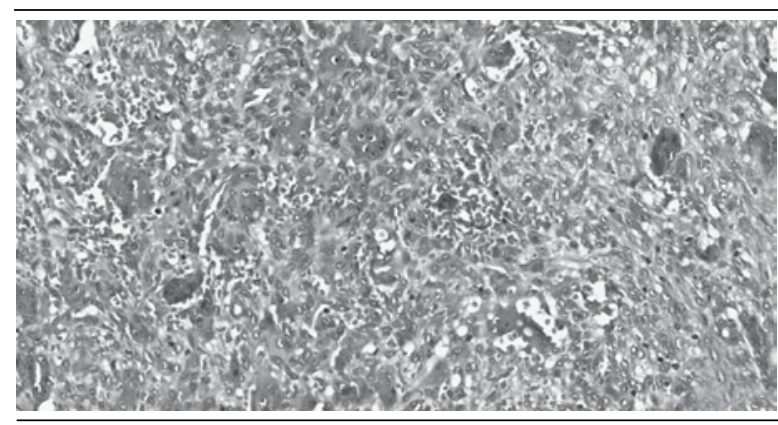

FIGURE 3 -Photomicrography showing a non-aggressive CGCL (HE) CGCL: central giant cell lesion; HE: hematoxylin and eosin.

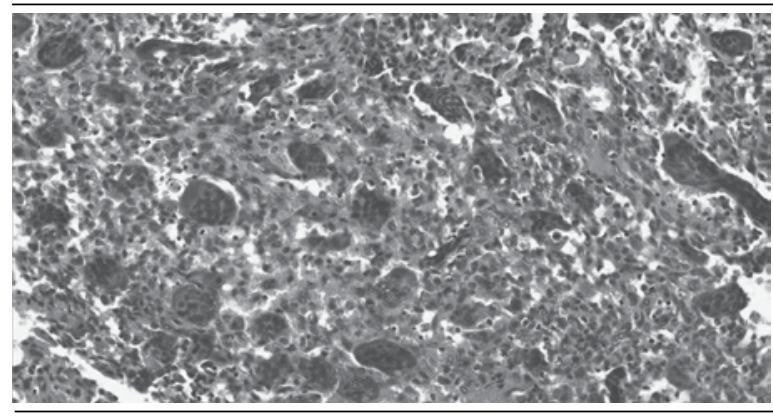

FIGURE 4 - Photomicrography showing an aggressive CGCL. There is a bigher number of giant and mesenchymal cells (HE)

HE: hematoxylin and eosin.

significant difference in terms of cell size. Other studies, however, found this difference. These authors observed that aggressive lesions showed a higher number of giant cells with more irregular shape. Additionally, the giant cells were larger. The mitotic activity was increased and differences in histomorphometric analysis of multinucleated giant cells may indicate not only an increase in the fusion of resident macrophages, recruitment of monocytes or both phenomena, but also a higher metabolic activity of multinucleated giant cells, which could be related to aggressive clinical behavior. Florez-Moreno et al. ${ }^{(14)}$ also reported that the nuclei of multinucleated giant cells from CGCL are larger, more numerous and irregular when compared to the multinucleated giant cells from PGCL, which could explain their distinct clinical behavior.

There is evidence that the giant cells from CGCL may be osteoclasts or macrophages. The differentiation mechanism would be through RANK-RANKL interaction, similarly to giant cells from PGCL, as described previously ${ }^{(13,14,16,21,27)}$. The proliferation component of CGCL is the mesenchymal stromal cells that are able to differentiate into fibroblast / osteoblast lineages. It was noted that stromal-derived cells induce osteoclast formation from monocytes in the presence of macrophage colony- stimulating factor (M -CSF) and in the absence of soluble RANKL ${ }^{(16)}$. 
Recently, a strong expression of nuclear factor of activated $\mathrm{T}$ cells (NFATc1), a factor of osteoclastogenesis probably involved in bone resorption, has been observed in giant cells from CGCL, cherubism and brown tumor of hyperparathyroidism ${ }^{(10,18)}$. In a simplified view of osteoclastogenesis, osteoclast precursor cells from bone marrow are involved in osteoclast differentiation by intranuclear accumulation of NFATCI. This factor is amplified by both the presence of SH3BP2 protein, encoded by the same gene, and RANK stimulation. The osteoblast expression of RANKL, in turn, is stimulated by PTH. Thus, the end result of PTH secretion is the proliferation of osteoclasts, bone resorption and release of calcium. Therefore, the pathological rise in PTH would cause brown tumor of hyperparathyroidism, consisting of mononuclear osteoclast precursors and differentiated multinucleated osteoclasts ${ }^{(10,18,37)}$.

NFATc1 protein, initially localized in the cytoplasm, is activated after RANKL signaling in osteoclast precursor cells. RANKL stimulation promotes the formation of a complex containing a second messenger, SH3BP2, which results in higher intracellular calcium levels. Increased calcium levels promote the displacement of NFATc1 into the nucleus where it binds to its own promoter. This binding leads to self-amplification of NFATc1 and activation of specific osteoclastogenesis genes ${ }^{(10,18)}$.

It has been proposed that oval to spindle-shaped mesenchymal cells are responsible for the biological activity of multinucleated giant cells ${ }^{(13)}$. Studies that assessed the phenotype of mesenchymal and multinucleated giant cells from CGCL and PGCL reported strong immunoreactivity for anti-CD68 antibody, suggesting that they belong to the macrophage lineage, though immunostaining was more evident in CGCL rather than PGCL ${ }^{(14)}$.

Regarding differential diagnosis, small unilocular lesions may be radiographically confused with granulomas and periapical cysts. When they are multilocular, they may be confused with ameloblastomas or other lesions. Histopathologically, they greatly resemble PGCL, aneurysmal bone cysts, central odontogenic fibroma, brown tumor of hyperparathyroidism, giant cell tumor and cherubism, particularly the latter when the lesion occurs in children and involves multiple locations ${ }^{(26,32)}$. It is noteworthy that CGCL and brown tumor of hyperparathyroidism are histologically similar, especially in cases in which there is intense endogenous brownish pigmentation of hemosiderin. Therefore, it is essential to request additional tests such as serum calcium, phosphate, parathyroid hormone and alkaline phosphatase, whose values are normal in CGCL ${ }^{(6,19,24,25,32,37)}$.

Due to their singular biological behavior and therapeutic implications, the differential diagnosis between CGCL and giant cell tumor is crucial. The bone giant cell tumor usually occurs in the epiphyses of long bones and it is rare in the skull, whereas CGCL usually occur in the mandible and maxilla. Both lesions appear as osteolytic defects in radiographic examination and should be distinguished by histology. Histological examination reveals that giant cells are larger, more numerous and more rounded in bone giant cell tumors. Additionally, they show higher number of nuclei, which are more evenly dispersed in comparison with the giant cells from CGCL. The giant cell tumor presents fewer foci of osteoid material, areas of hemorrhage, deposition of hemosiderin and fibrosis. The stroma of giant cell tumor is composed of large round and oval cells, which are next to each other. The aneurysmal bone cyst is distinguished from CGCL due to its network of multiple cystic cavities filled with blood within thin walls ${ }^{(21,26,32)}$

Treatment of CGCL is associated with its clinical behavior. In milder cases, a simple surgical resection followed by a thorough curettage is recommended. Nevertheless, in aggressive lesions, curettage is followed by cryosurgery, peripheral osteotomy or en bloc resection. Some treatments involve daily local application of calcitonin, corticosteroids and subcutaneous injection of interferon- $2 \alpha$. Intralesional injections of triamcinolone acetonide have also been prescribed in view of its anti-inflammatory and antiangiogenic properties. The combined treatment (pharmacological and surgical) is advantageous for large aggressive lesions insofar as it reduces their size, minimizing functional and physical imperfections ${ }^{(4,8,10,21,23,25,26,29)}$. The anti-angiogenic therapy in combination with curettage has proven to be a useful approach to the treatment of aggressive $\mathrm{CGCL}^{(25)}$.

The Table summarizes the main aspects that differentiate PGCL from CGCL according to what has been outlined in this review.

TABLE 2 - Main aspects of PGCL and CGCL according to the present review

\begin{tabular}{lll}
\hline & \multicolumn{1}{c}{ PGCL } & \multicolumn{1}{c}{ CGCL } \\
\hline Etiology & Local irritant factors & Uncertain \\
Nature & Non-neoplastic & Non-neoplastic \\
Site & $\begin{array}{l}\text { Extraosseous: gingiva } \\
\text { and alveolar ridge }\end{array}$ & Intraosseous \\
Clinical behavior & Little aggressive & More aggressive \\
Recurrence potential & Low & High \\
Histology & Similar to CGCL & Similar to PGCL \\
Origin of giant cells & Uncertain & Uncertain \\
Growth & Exophytic, slow & Endophytic, rapid \\
Bone resorption & Rare & Present \\
Dental root resorp- \\
tion & Rare & Present \\
Treatment & & \\
& Surgical & Pharmacological and/ \\
\hline
\end{tabular}

PGCL: peripheral giant cell lesions; CGCL: central giant cell lesions. 


\section{Final remarks}

PGCL and CGCL are entities that arise in the peripheral (gum) or center (bone) regions, respectively. The true nature of CGCL remains unknown and it has not been clarified whether the lesion has a reactive, infectious, neoplastic or inflammatory origin. A consensus has not been reached in the literature whether the two lesions have different behaviors or whether they are really different entities.
The exact origin of giant cells is also uncertain. Opinions differ and they may originate from osteoblasts, phagocytes, endothelial or oval/spindle-shaped mesenchymal cells. The pathogenesis of PGCL and maxillary CGCL is also contentious. Some researchers believe that CGCL may be reactive, although more aggressive cases may be considered true neoplasms. Several studies have focused on the histopathological assessment and immunohistochemical parameters as reliable indicators and predictors of their clinical behavior and prognosis, however, the results are still inconclusive.

\section{RESUMO}

Introdução e objetivo: As lesões periféricas e centrais de células gigantes (LPCG e LCCG) constituem um grupo de entidades patológicas com características histopatológicas semelhantes e natureza incompletamente elucidadas. A primeira lesão apresenta caráter reacional, enquanto a segunda, comportamento proliferativo de natureza não neoplásica. O artigo tem como objetivo fazer revisão de literatura sobre as LPCGs e as LCCGs, discutindo os aspectos mais importantes inerentes a cada uma delas. Resultados: As duas lesões apresentam localização e comportamento clínico distintos, apesar de exibirem as mesmas características histopatológicas. O tratamento para ambas as lesões consiste na remoção cirúrgica, mas com técnicas distintas, dependendo do tipo da lesão e do estado clínico, sendo que no caso da LCCG uma terapêutica medicamentosa também pode ser empregada. Conclusão: Embora não haja um consenso na literatura, é fundamental que se conheça a etiologia dessas lesões, bem como a exata origem das células gigantes. Por causa de seus comportamentos biológicos diferentes, torna-se importante realizar o diagnóstico diferencial entre ambas as lesões e outros processos que apresentem características clínicas, radiográficas ou histológicas semelhantes, visto que esse procedimento é essencial para executar um tratamento adequado e estabelecer um prognóstico.

Unitermos: lesão periférica de células gigantes; lesão central de células gigantes; gengiva; maxila; mandíbula.

\section{REFERENCES}

1. AMARAL, F. R. et al. NFATc1 and TNFalpha expression in giant cell lesions of the jaws. J Oral Pathol Med, v. 39, n. 3, p. 269-74, 2010.

2. AMARAL, F. R. et al. Quantitative expression analysis of apoptotic/ antiapoptotic genes and association with immunolocalization of BAX and BCL-2 in peripheral and central giant cell lesions of the jaws. Tumour Biol, v. 32, n. 5, p. 997-1003, 2011.

3. BANSAL, P. et al. Non-syndromic multiple impacted supernumerary teeth with peripheral giant cell granuloma. Contemp Clin Dent, v. 2, n. 1, p.41-4, 2011.

4. BI, Y. et al. Bisphosphonates cause osteonecrosis of the jaw-like disease in mice. Am J Pathol, v.177, n. 1, p. 280-90, 2010.

5. CARVALHO, V. M. et al. Novel mutations in the SH3BP2 gene associated with sporadic central giant cell lesions and cherubism. Oral Dis, v. 15, n. 1, p. 106-10, 2009.

6. DARYANI, D.; GOPAKUMAR, R. Central giant cell granuloma mimicking an adenomatoid odontogenic tumor. Contemp Clin Dent, v. 2, n. 3, p. 249-52, 2011.
7. DA SILVA, N. G. et al. Treatment of central giant cell lesions using bisphosphonates with intralesional corticosteroid injections. Head Face Med, v. 8, n. 23, p. 1-6, 2012.

8. DA SILVA SAMPIERI, M. B. et al. Central giant cell granuloma: treatment with calcitonin, triamcinolone acetonide, and a cystic finding 3 years and 6 months after the primary treatment. Oral Maxillofac Surg, Oct 31, [Epub ahead of print], 2012.

9. DE MATOS, F. R. et al. Immunoexpression of TNF- $\alpha$ and TGF- $\beta$ in central and peripheral giant cell lesions of the jaws. J Oral Pathol Med, v. 41, n. 2, p.194-9, 2012.

10. DUARTE, A. P. et al. Increased expression of NFATc1 in giant cell lesions of the jaws, cherubism and brown tumor of hyperparathyroidism. Oncology Letters, v. 2, n. 3, p. 571-3, 2011.

11. ETOZ, 0. A. et al. The peripheral giant cell granuloma in edentulous patients: report of three unique cases. Eur J Dent, v. 4, n. 3, p. 329-33, 2010.

12. FANOURAKIS, G. et al. Expression of receptor activator of NF- $\kappa \mathrm{B}$ ligand and osteoprotegerin in peripheral giant cell granulomas of the jaws. J Oral Pathol Med, v. 39, n. 9, p. 687-9, 2010.

13. FERRETTI, C.; MUTHRAY, E. Management of central giant cell granuloma of mandible using intralesional corticosteroids: case report 
and review of literature. J Oral Maxillofac Surg, v. 69, n. 11, p. 2824-9, 2011.

14. FLOREZ-MORENO, G. A. et al. Cytomorphometric and immunohistochemical comparison between central and peripheral giant cell lesions of the jaws. Oral Surg Oral Med Oral Pathol Oral Radiol Endod, v. 105, n. 5, p. 625-32, 2008.

15. FRIEDRICH, R. E. et al. Expression of proteases in giant cell lesions of the jaws, tendon sheath and salivary glands. Anticancer Res, v. 30, n. 5, p. 1645-52, 2010

16. ITONAGA, I. et al. Cellular mechanisms of osteoclast formation and lacunar resorption in giant cell granuloma of the jaw.J Oral Pathol Med, v. 32, n. 4, p. 224-31, 2003.

17. KRUSE-LOSLER, B. et al. Central giant cell granuloma of the jaws: a clinical, radiologic, and histopathologic study of 26 cases. Oral Surg Oral Med Oral Pathol Oral Radiol Endod, v. 101, n. 3, p. 346-54, 2006.

18. LIETMAN, S. A. et al. SH3BP2 is an activator of NFAT activity and osteoclastogenesis. Biochem Biophys Res Commun, v. 371, n. 4, p. 644-8, 2008

19. LIU, B.; YU, S. F.; LI, T. J. Multinucleated giant cells in various forms of giant cell containing lesions of the jaws express features of osteoclasts. $J$ Oral Pathol Med, v. 32, n. 6, p. 367-75, 2003

20. MANNEM, S.; CHAVA, V. K. Management of an unusual peripheral giant cell granuloma: a diagnostic dilemma. Contemp Clin Dent, v. 3 , n. 1, p. 93-6, 2012.

21. NEVILLE, B. W. et al. Patologia oral \& maxilofacial. 2. ed. Rio de Janeiro: Guanabara Koogan, 2009. 798p.

22. NOGUEIRA, R. L. et al. Cyclooxygenase-2 expression in central giant cell lesion of the jaws: an immunohistochemical study.J Mol Histol, v. 43 , n. 1, p. 59-62, 2012.

23. NOGUEIRA, R. L. et al. Intralesional injection of triamcinolone hexacetonide as an alternative treatment for central giant-cell granuloma in 21 cases. Int J Oral Maxillofac Surg, v. 39, n. 12, p. 1204-10, 2010.

24. NOLETO, J. W. et al. Aspectos radiológicos e epidemiológicos do granuloma central de células gigantes. Radiol Bras, v. 40, n. 3, p. $167-$ 71,2007 .

25. OCONNELL, J. E.; KEARNS, G. J. Aggressive giant cell granuloma of the jaws treated with interferon alpha: a report of two cases. Ir J Med Sci, [Epub ahead of print], 2012.
26. ORHAN, E. et al. Idiopathic bilateral central giant cell reparative granuloma of jaws: a case report and literature review. Int J Pediatr Otorhinolaryngol, v. 74, n. 5, p. 547-52, 2010.

27. PAPANICOLAOU, P. et al. Increased TNF- $\alpha$, IL- 6 and decreased IL$1 \beta$ immunohistochemical expression by the stromal spindle-shaped cells in the central giant cell granuloma of the jaws. Med Oral Patol Oral Cir Bucal, v. 17, n. 1, p. 56-62, 2012.

28. QUINDERÉ, L. B. et al. Expressão imuno-histoquímica de colágeno IV, tenascina-C e fibronectina em lesões centrais e periféricas de células gigantes. Rev Inst Ciênc Saúde, v. 26, n. 2, p. 226-31, 2008.

29. RACHMIEL, A. et al. Combined treatment of aggressive central giant cell granuloma in the lower jaw. J Craniomaxillofac Surg, v. 40, n. 3, p. 292-7, 2012.

30. REDDY, V. et al. Incidence of central giant cell granuloma of the jaws with clinical and histological confirmation: an archival study in Northern India. Br J Oral Maxillofac Surg, v. 50, n. 7, p. 668-72, 2012.

31. SAYGUN, I. et al. Human cytomegalovirus in peripheral giant cell granuloma. Oral Microbiol Immunol, v. 24, n. 5, p. 408-10, 2009.

32. SAW, S. et al. Giant cell tumour and cen-tral giant cell reparative granuloma of the skull: do these represent ends of a spectrum? A case report and literature review. Pathol Oncol Res, v. 15, n. 2, p. 291-5, 2009.

33. SOUZA, P. E.; MESQUITA, R. A.; GOMEZ, R. S. Evaluation of p53, PCNA, $\mathrm{Ki}-67, \mathrm{MDM} 2$ and AgNOR in oral peripheral and central giant cell lesions. Oral Dis, v. 6, n. 1, p. 35-9, 2000.

34. TANDON, P. N. et al. Peripheral giant cell granuloma. Contemp Clin Dent, v. 3, n. 1, (Suppl 1), p. 118-21, 2012.

35. TEIXEIRA, R. C. et al. SH3BP2-encoding exons involved in cherubism are not associated with central giant cell granuloma. Int JOral Maxillofac Surg, v. 40, n. 8, p. 851-5, 2011.

36. TORABINIA, N.; RAZAVI, S. M.; SHOKROLAHI, Z. A comparative immunohistochemical evaluation of CD68 and TRAP protein expression in central and peripheral giant cell granulomas of the jaws.J Oral Pathol Med, v. 40, n. 4, p. 334-7, 2011.

37. VALENTINE, J. C.; NELSON, B. L. Central giant cell lesion. Head Neck Pathol, v. 5, n. 4, p. 385-8, 2011.

\section{MAILING ADDRESS}

